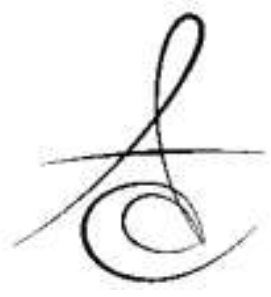

\section{DİŞ HEKİMLİĞİ ÖĞRENCİLERİNİN SAĞLIKLI YAŞAM BİÇİMİ DAVRANIŞLARININ DEĞERLENDİRİLMESİ}

\section{EVALUATION OF HEALTHY LIFESTYLE BEHAVIOURS OF DENTAL STUDENTS}

\author{
Dr. Öğr. Üyesi Osman Fatih ARPAĞ* Dr. Öğr. Üyesi Mehmet ADIGÜZEL** \\ Dr. Öğr. Üyesi Caner ÖZTÜRK ${ }^{* * *}$
}

Osman Fatih Arpağ: ORCID ID: 0000-0002-1510-8917

Mehmet Adıgüzel: ORCID ID: 0000-0002-9363-6264

Caner Öztürk: ORCID ID: 0000-0001-9549-2770

\title{
öz
}

Amaç: Bu çalışmanın amacı diş hekimliği öğrencilerinin sağlıklı yaşam biçimi davranışlarını değerlendirmektir.

Gereç ve yöntem: Bu çalışma Hatay Mustafa Kemal Üniversitesi'nde lisans eğitimi alan toplam 215 diş hekimliği fakültesi öğrencileri üzerinde yürütüldü. Katııımcılara sağlıklı yaşam biçimi davranış ölçeği II ve sosyo-demografik verileri içeren anket soruları katıımcılara elektronik posta ile gönderildi. Yanıt havuzundan derlenen veriler Excel formatına getirilerek istatistiksel analiz için için bir bilgisayar yazııımına aktarıldı. Elde edilen veriler, Çok Yönlü Varyans Analizi ve Tukey Çoklu Karşılaştırma testi kullanılarak $p<0,05$ anlamlıık düzeyinde değerlendirildi. Ayrıca bireylerden elde edilen nicel verilerin karşılıklı ilişkisi ise Pearson korelasyon analizi kullanılarak $p<0,05$ anlamlılık düzeyinde değerlendirildi.

Bulgular: Farklı sınıflarda eğitim gören bireylerin sağlıklı yaşam biçimi davranışları toplamında ve alt boyutlarında herhangi bir istatistiksel farklılık gözlenmedi ( $p>0,05)$. Manevi gelişim, sağlık sorumluluğu, fiziksel aktivite, beslenme, kişilerarası destek ve stresle baş-etme alt boyutlarında sınıfların ortalama değerin üzerinde yanıt verdikleri belirlendi. Katılımcılar arasında en düşük skor, 16,73 ile fiziksel aktivite alt boyutunda, en yüksek skor ise 24,92 ile kișiler arası destek alt boyutunda elde edildi $(p<0,05)$. Sonuç: Bireylerin okul eğitim derecesi ile sağlıklı yaşam biçimi davranışları ile okul eğitim derecesi arasında anlamlı bir ilişki yoktur. Bazı sosyo-demografik faktörlerin bireylerin sağlıklı yaşam biçimi davranışı üzerinde istatistiksel olarak daha fazla etkilidir.

Anahtar kelimeler: Diş hekimliği lisans öğrencisi, sağlığın geliştirilmesi, sağlıklı yaşam biçimi davranış ölçeği.

\section{ABSTRACT}

Aim: The aim of this study was to evaluate the healthy lifestyle behaviors of dental students.

Material and method: This study conducted with 215 dental students at Hatay Mustafa Kemal University. Healthy lifestyle behaviors Scale II and the questionnaire including socio-demographic data were sent to all students by e-mail. The data was incorporated in Excel format and then transferred to software for statistical analyses. The data were evaluated by using multivariate variance analyses and Tukey post-hoc comparison test at a significance level of 0.05 . The relationship between the quantitative variables was evaluated by using Pearson correlation test at a significance level of 0.05 .

Reults: There is no difference between the classes in terms of healthy lifestyle behaviors and its subclasses $(p>0.05)$. All the classes answered over the average value for subclasses "spiritual growth", "health responsibility", "physical activity", "nutrition", "interpersonal relationships" and "stress management". The participants obtained the lowest score (16.73) in physical activity subclasses, but scored $(24.92)$ the highest one in interpersonal relationships subclasses. $(p<0.05)$

Conclusion: No associations between healthy lifestyle behaviors and the degree of education were observed. The sociodemographic data has an effect on the students with regard to the present healthy lifestyle behaviors.

Keywords: Dental student, health promotion, healthy lifestyle behaviors

\footnotetext{
* Hatay Mustafa Kemal Üniversitesi Diş Hekimliği Fakültesi Periodontoloji AD, Hatay.

${ }^{* *}$ Hatay Mustafa Kemal Üniversitesi Diş Hekimliği Fakültesi Endodonti AD, Hatay.

*** Hatay Mustafa Kemal Üniversitesi Diş Hekimliği Fakültesi Protetik Diş Tedavisi AD, Hatay
}

Kaynakça Bilgisi: Arpağ OF, Adıgüzel M, Öztürk C. Diş Hekimliği Öğrencilerinin Sağlıklı Yaşam Biçimi Davranışlarının Değerlendirilmesi. Atatürk Üniv Diş Hek Fak Derg 2020; 30: 233-241.

Citation Information: Arpag OF, Adiguzel M, Ozturk C. Evaluation of Healthy Lifestyle Behaviours of Dental Students. J Dent Fac Atatürk Uni 2020; 30: 233-241. 


\section{GİRİŞ}

Dünya Sağlık Örgütü'ne göre sağlık; hastalık ve sakatlığın olmaması değil bunun yanında bedensel, ruhsal ve sosyal yönden tam bir iyilik hali olarak tanımlanmaktadır. Bu tanıma göre; eğitimsizlik, kötü beslenme, barınma ortamının yetersizliği, işsizlik, ağır meslekler, düşük gelir düzeyi, yoğun sportif aktiviteler ve kötü alışkanlıklar gibi birçok faktör sağlğı olumsuz yönde etkilemektedir. ${ }^{1}$ Dolayısıyla sağlıkı olabilmek ve hatta hayatta kalabilmek için sağlıklı yaşam biçimi davranışlarının yaşam boyu gerçekleştirilmesi gerekmektedir. Literatürdeki verilere göre az gelişmiş toplumlardaki ölümlerin \% 75 civarı yaşam biçimine bağlı gözlenen hastalıklara bağlanmaktadır. Özellikle de bu toplumlarda yaygın görülen ve bulaşıcı olmayan kronik hastalıkların günümüzde ciddi ölüm sebebi sayılabileceği belirtilmektedir. Örneğin; sigara kullanımı kronik obstrüktif akciğer hastalığı ve kardiyovasküler problemlere neden olmakta kronik hastalıkların uzun vadeli etkilerinin sonucu olarak yaşam kalitesi

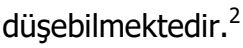

Sağlık kavramının toplumda yerleştirilebilmesi için birçok aktivite ve fiziksel ortamlar oluşturulmaktadır. Bunların başında sağık bakanlığının girişimleri, üniversiteler, belediyeler, sağlık kuruluşları, sivil toplum kuruluşları ve sağlık personellerinin çeşitli çabaları gelmekle birlikte yazııı ve görsel medyanın sağlıkı yaşam ile ilgili çeşitli bilgilendirme eylemleri küçümsenmeyecek boyutta olmaktadır. Sağlıkı bir toplumun oluşturulmasında kişilerin sağlık konusundaki algılarının yanı sıra sağlık sorumlularının rolü tartışımazdır. ${ }^{3,4}$ Toplumda yaygın görülen ağız hastalıklarının önlenmesi ve sağlğın geliştirilmesinde diş hekimlerinin önemli bir yeri vardır. Ancak ergonomik olmayan pozisyonda uzun süreli ve tempolu çalışmak, dengesiz beslenmek, egzersizden uzak stresli bir yaşam biçimi ve kötü alışkanlıklar gibi yaşam koşulları ve mevcut imkânlar her bireyde olduğu gibi diş hekimlerinin de sağılıkı yaşam biçimi davranışlarının yaşam boyu gerçekleştirilmesini engellemekte ve sağlığı üzerinde ciddi olumsuz etkileri olmaktadır. Yine sağlığın geliştirilmesinde sağlık eğitiminin de önemli bir etkisi vardır. Sağlık eğitimi konusundaki bilgi düzeyi ve sorumluluk duygusu artıkça hastalık ve rahatsızlıkların oranında ters orantılı olarak düşüşler meydana gelmiştir. ${ }^{5-7}$

Sağlığın geliştirilmesine yönelik yaşam biçimi davranışlarının ölçüldüğü çalışmalarda Pender'in sağlığı geliştirme modelini temel alan $^{8}$ ve Walker ve arkadaş- larının 1987 yılında geliştirdiği ölçek yaygın bir şekilde kullanım alanı bulmuştur. ${ }^{9}$ Bu ölçek sağlık sorumluluğu, kişiler arası destek, kendini gerçekleştirme, egzersiz, beslenme ve stres yönetimi başlıkları altında toplam 48 soru içermektedir. Bu ölçek, 1996 yilında 4 soru daha eklenerek yeniden düzenlenmiştir. ${ }^{10}$ Ölçeğin geçerliliği ve güvenilirliği yapılmıştır. Pınar ve arkadaşlarının yaptığı bir çalışmada sağlıkı yaşam biçimi davranış ölçeğinin Türk toplumlarında güvenle kullanılabileceği belirtilmektedir. ${ }^{11}$

Diş hekimlerinin toplum sağıı̆ını geliştirmelerindeki etkileri bilgi birikimlerinin yanı sıra sağılıkı yaşam biçimi davranışları ile şekillenmektedir. Dolayısıyla bu çalışmanın amacı diş hekimliği lisans öğrencilerinin eğitim seviyeleri ve sosyo-demografik verilerinin sağlıklı yaşam biçimi davranış ölçütleri üzerine etkisini değerlendirmektir. Bu çalışmanın sıfır hipotezi ise, bireylerin lisans eğitim düzeyi ve sosyo-demografik verilerinin bireylerin sağlıkı yaşam biçimi davranış ölçütleri üzerine etkisi yoktur şeklinde kurulmuştur.

\section{GEREÇ ve YÖNTEM}

Çalışmamızın yürütülmesi için gerekli olan etik kurul onayı Hatay Mustafa Kemal Üniversitesi Etik Kurulundan alındı (No: 28.12.2017/20). Çalışma 20172018 yıllarında Hatay Mustafa Kemal Üniversitesi Diş Hekimliği Fakültesi'nde lisans eğitimi alan toplam 215 öğrenci üzerinde yürütüldü. Dijital ortamda "Google Formlar"da hazırlanan sosyo-demografik veri anket formu ve Sağılıkı Yaşam Biçimi Davranış Ölçeği II, önceden kaydedilen mail adreslerine gönderildi.

Gönülülere; yaş, boy, kilo, cinsiyet, anne-baba eğitim durumu, aylık gelir, kardeş sayısı, meslek memnuniyet durumu, sınıf düzeyi ve çeşitli sorulardan oluşan 29 soruluk bir anket formu doldurtuldu. Sağıklı Yaşam Biçimi Davranışları için ise gönüllülerden, 52 maddeden oluşan ve manevi gelişim $(6,12,18,24,30$, $36,42,48,52)$, sağlık sorumluluğu $(3,9,15,21,27,33,39$, $45,51)$, fiziksel aktivite $(4,10,16,22,28,34,40,46)$, beslenme $\quad(2,8,14,20,26,32,38,44,50)$, kişiler-arası destek $(1,7,13,19,25,31,37,43,49)$ ve stresle baş-etme $(5,11,17,23,29,35,41,47)$ şeklinde 6 alt başlık içeren ölçeğin doldurulması istendi. Maddeler ölçekte dağınık bir şekilde verilmiş, benzer soru izlenimi oluşturmamak ve cevapları etkilememek adına herhangi bir tasnif yapılmamıştır. Ölçeğin değerlendirmesi 4'lü likert şeklinde olup, yanitlar "hiçbir zaman" (1), "bazen" (2), "sık" (3) ve "düzenli olarak" (4) şeklinde skorlanarak derecelendirilmiş ve ölçeğin tamamı için en düşük 52, en yüksek 208 puan olarak belirlenmiştir. (Tablo 1) 
Tablo 1. Sağlıklı yaşam biçimi davranış ölçeğine ilişkin gruplar, sorular ve asgari ve azami puan karşılıkları.
Tablo 2. Öğrencilerin sosyo-demografik değişkenlerinin dağılımı

\begin{tabular}{|l|r|c|}
\hline Alt boyutlar & Sorular & $\begin{array}{c}\text { En düşük } \\
\text { toplam } \\
\text { puaan }\end{array}$ \\
\hline Manevi gelişim & $6,12,18,24,30,36,42,48,52$ & 9 \\
\hline Sağlık sorumluluğu & $3,9,15,21,27,33,39,45,51$ & 9 \\
\hline Fiziksel aktivite & $4,10,16,22,28,34,40,46$ & 8 \\
\hline Beslenme & $2,8,14,20,26,32,38,44,50$ & 9 \\
\hline Kişilerarası destek & $1,7,13,19,25,31,37,43,49$ & 9 \\
\hline Stresle baş-etme & $5,11,17,23,29,35,41,47$ & 8 \\
\hline $\begin{array}{l}\text { Sağlıklı yaşam biçimi } \\
\text { davranış ölçeği }\end{array}$ & $1-52$ & 52 \\
\hline
\end{tabular}

Formları dolduran gönüllülerin yanıtları Google tarafından oluşturulan bir havuza aktarıldı ve Excel dosyası halinde çıktı alındı. Verilerin analizi bir bilgisayar yazılım yardımıyla (SPSS 20, IBM Corp. USA) yapıldı. Gruplar arasındaki kategorik değişkenlerin dağıımları arasındaki fark Ki-kare testi kullanılarak $p<0,05$ anlamlılık düzeyinde belirlendi. Gruplardan elde edilen nicel verilerin normalliği Shapiro Wilks testi kullanılarak, homojenliği ise Levene's testi kullanılarak değerlendirildi. Gruplardan elde edilen nicel veriler arasındaki fark ise Bonferroni düzeltmesi uygulanarak (a:0,05) Çok Yönlü Varyans Analizi ve Tukey Çoklu Karşılaştırma Testi kullanılarak $\mathrm{p}<0,05$ anlamlılık düzeyinde değerlendirildi. Ayrıca bireylerden elde edilen nicel verilerin karşılıklı ilişkisi ise Pearson korelasyon analizi kullanılarak $p<0,05$ anlamlılık düzeyinde değerlendirildi.

\section{BULGULAR}

$\mathrm{Bu}$ çalışmada toplam öğrenci sayısı sınıflara göre dağılımı tablo 2'de gösterilmiştir. Genel yaş ortalaması 21.13 olan öğrencilerin \%53'ü kadın (114), \% 47'si ise erkek (101) idi. Doğum yeri (coğrafi bölge olarak), aile gelir düzeyi, kardeş sayısı, anne ve baba eğitim durumu, sistemik sağlık durumu, diş fırçalama sıklığı, diş hekimine gitme sıklığı, mesleki memnuniyet (bölüm memnuniyeti), beslenme tipi, sigara ve alkol kullanma durumuna ilişkin tanımlayıcı istatistiksel veriler yüzdeleri ile birlikte Tablo 2'de gösterilmektedir.

Sağlıklı yaşam biçimi davranış ölçeğinin alt başlıkları açısından değerlendirildiğinde sınıf düzeyinde istatistiksel açıdan bir fark olmadığı saptandı ( $p>0,05)$. Manevi gelişim, sağlık sorumluluğu, fiziksel aktivite, beslenme, kişilerarası destek ve stresle baş-etme alt gruplarında sınıfların ortalama değerin üzerinde yanıt verdikleri gözlendi. Yine sağıklı yaşam biçimi davranış ölçeği alt başlıklarında ve toplamda tüm öğrenciler

\begin{tabular}{|l|l|} 
& \multicolumn{1}{|c|}{ D } \\
\cline { 3 - 3 } & \\
\hline 36 & \\
\hline 36 & \\
\hline 32 & \\
\hline 36 & \\
\hline 36 & \\
\hline 32 & \\
\hline 208 &
\end{tabular}

\begin{tabular}{l|l|l|l} 
Sinıfı & & & \\
\hline 1. & Sinıf & 62 & \\
\hline
\end{tabular}

\begin{tabular}{l|l|l|l|}
\hline 2. & sinıf & 36 & 16,7 \\
\hline 3. & SInıf & 40 & 18,6 \\
\hline 4. & Sinıf & 41 & 19,1
\end{tabular}

\begin{tabular}{l|l|l|l}
\hline 4. & Sinif & 40 & 18,6 \\
\hline 5. & & 41 & 19,1
\end{tabular}

\begin{tabular}{r|r|l|l}
5. & Sinif & 36 & 16,7 \\
\hline
\end{tabular}

Yaş ortalaması Cinsiyet

\begin{tabular}{|l|l|l}
\hline kadin & & \\
\hline & 114 & 53,0 \\
\hline
\end{tabular}

\begin{tabular}{|l|l|l}
\hline erkek & 114 & 53,0 \\
\hline Vücut kitle indeksi & 101 & 47,0
\end{tabular}

Doğum yeri (coğrafi bölge)

\begin{tabular}{|c|c|c|}
\hline Akdeniz & 143 & 66,5 \\
\hline Doğu Anadolu & 13 & 6,0 \\
\hline Ege & 6 & 2,8 \\
\hline Güneydoğu Anadolu & 40 & 18,6 \\
\hline İç Anadolu & 6 & 2,8 \\
\hline Karadeniz & 2 & 0,9 \\
\hline Marmara & 5 & 2,3 \\
\hline \multicolumn{3}{|l|}{ Meslek memnuniyeti } \\
\hline memnun olmayan & 4 & 1,9 \\
\hline kısmen memnun & 35 & 16,3 \\
\hline memnun & 122 & 56,7 \\
\hline çok memnun & 49 & 22,8 \\
\hline fikri olmayanlar & 5 & 2,3 \\
\hline \multicolumn{3}{|l|}{ Aylık gelir (aile) } \\
\hline $700 \mathrm{TL}$ ve altı & 9 & 4,2 \\
\hline 701-1450 TL & 35 & 16,3 \\
\hline $1451-2900 \mathrm{TL}$ & 80 & 37,2 \\
\hline 2900 TL üzeri & 91 & 42,3 \\
\hline \multicolumn{3}{|l|}{ Aylık harcama (kendisi) } \\
\hline $450 \mathrm{TL}$ ve altı & 71 & 33,0 \\
\hline $451-900 \mathrm{TL}$ & 100 & 46,5 \\
\hline 901 TL ve üzeri & 44 & 20,5 \\
\hline \multicolumn{3}{|l|}{ Kardeş sayısı } \\
\hline $1-2$ & 127 & 59,1 \\
\hline $3-4$ & 55 & 26,6 \\
\hline 5 ve üzeri & 33 & 15,3 \\
\hline \multicolumn{3}{|l|}{ Anne eğitim durumu } \\
\hline okur-yazar değil & 14 & 6,5 \\
\hline okur-yazar & 13 & 6,0 \\
\hline ilkokul & 78 & 36,3 \\
\hline ortaokul-lise & 60 & 27,9 \\
\hline üniversite & 50 & 23,3 \\
\hline \multicolumn{3}{|l|}{ Baba eğitim durumu } \\
\hline okur-yazar değil & 4 & 1,9 \\
\hline okur-yazar & 5 & 2,3 \\
\hline ilkokul & 59 & 27,4 \\
\hline ortaokul-lise & 63 & 29,3 \\
\hline üniversite & 84 & 39,1 \\
\hline \multicolumn{3}{|l|}{ Beslenme tipi } \\
\hline karbonhidrat ağırlıklı & 32 & 14,9 \\
\hline protein ağırlıklı & 20 & 9,3 \\
\hline sebze-meyve ağırlıkı & 4 & 1,9 \\
\hline karışık & 159 & 74,0 \\
\hline \multicolumn{3}{|l|}{ Sigara } \\
\hline var & 60 & 27,9 \\
\hline yok & 155 & 72,1 \\
\hline \multicolumn{3}{|l|}{ Alkol } \\
\hline var & 92 & 42,8 \\
\hline yok & 123 & 57,2 \\
\hline \multicolumn{3}{|l|}{ Sistemik hastalık durumu } \\
\hline sağlıklı & 632 & 29,3 \\
\hline sistemik hastalıklı & 152 & 70,7 \\
\hline \multicolumn{3}{|l|}{ Aile içi iletişim durumu } \\
\hline cevapsız & 3 & 1,4 \\
\hline kötü & 5 & 2,3 \\
\hline orta & 33 & 15,3 \\
\hline iyi & 104 & 48,4 \\
\hline çok iyi & 70 & 32,6 \\
\hline \multicolumn{3}{|l|}{ Diş fırçalama sıklığı } \\
\hline günde 1 & 33 & 15,3 \\
\hline günde 2 & 150 & 69,8 \\
\hline günde 3 ve üzeri & 23 & 10,7 \\
\hline ihtiyaç hissettiğinde & 9 & 4,2 \\
\hline \multicolumn{3}{|l|}{ Diş hekimine gitme sıklığı } \\
\hline şikayeti olduğu zaman & 139 & 64,7 \\
\hline $3-6$ ayda 1 & 38 & 17,7 \\
\hline senede 1 & 17 & 7,9 \\
\hline gitmiyor & 21 & 9,8 \\
\hline
\end{tabular}


ARPAĞ, ADIGÜZEL,

ÖZTÜRK

Tablo 3. Sağlıkı yaşam biçimi davranış ölçeğinin alt boyutlarının sosyo-demografik veriler ile ilişkili ortalama ve standart sapma değerleri

\begin{tabular}{|c|c|c|c|c|c|c|c|}
\hline Değişkenler & Manevi gelişim & \begin{tabular}{|c|} 
Sağlık \\
sorumluluğu
\end{tabular} & Fiziksel aktivite & Beslenme & $\begin{array}{c}\begin{array}{c}\text { Kişilerarası } \\
\text { destek }\end{array} \\
\end{array}$ & \begin{tabular}{|c|}
$\begin{array}{c}\text { Stresle baş- } \\
\text { etme }\end{array}$ \\
\end{tabular} & Toplam \\
\hline Sinif & $23,85 \pm 3,49$ & $19,80 \pm 3,27$ & $16,98 \pm 4,14$ & $19,62 \pm 3,24$ & $25,17 \pm 3,94$ & $19,37 \pm 3,57$ & $124,82 \pm 15,11$ \\
\hline Sinif & $24,55 \pm 3,77$ & $21,50 \pm 3,77$ & $17,61 \pm 4,79$ & $19,58 \pm 3,63$ & $25,50 \pm 4,23$ & $19,77 \pm 3,97$ & $128,52 \pm 16,37$ \\
\hline SInif & $23,92 \pm 4,01$ & $20,92 \pm 3,90$ & $16,70 \pm 3,51$ & $20,20 \pm 3,63$ & $24,70 \pm 4,05$ & $19,25 \pm 3,54$ & $125,70 \pm 18,42$ \\
\hline Sinif & $24,17 \pm 4,04$ & $20,56 \pm 3,22$ & $16,43 \pm 4,41$ & $19,97 \pm 3,58$ & $23,92 \pm 3.10$ & $18,85 \pm 3,29$ & $124,41 \pm 14,33$ \\
\hline 5. $\quad$ Sinif & $24,72 \pm 3,24$ & $21,63 \pm 3,61$ & $15,80 \pm 3,94$ & $19,91 \pm 3,69$ & $25,30 \pm 3,15$ & $19,30 \pm 3,62$ & $126,69 \pm 15,79$ \\
\hline Ortalama & $24,19 \pm 3,69$ & $20,74 \pm 3,57$ & $16,73 \pm 4,17$ & $19,84 \pm 3,50$ & $24,92 \pm 3,75$ & $19,30 \pm 3,57$ & $125,84 \pm 15,87$ \\
\hline \multicolumn{8}{|l|}{ Cinsiyet } \\
\hline kadın & $23,86 \pm 0,41$ & $20,93 \pm 0,34$ & $15,84 \pm 0,46$ & $20,13 \pm 0,38$ & $25,18 \pm 0,40$ & $19,52 \pm 0,37$ & $125,63 \pm 1,69$ \\
\hline erkek & $24,47 \pm 0,44$ & $20,88 \pm 0,37$ & $17,60 \pm 0,49$ & $19,63 \pm 0,41$ & $24,44 \pm 0,43$ & $19,06 \pm 0,39$ & $126,08 \pm 1,80$ \\
\hline p değeri & 0,339 & 0,925 & 0,101 & 0,381 & 0,212 & 0,399 & 0,856 \\
\hline \multicolumn{8}{|l|}{ Anne eğitim durumu } \\
\hline okur-yazar değil & $24,50 \pm 0,99$ & $18,80 \pm 083^{\mathrm{a}}$ & $16,42 \pm 1,10$ & $18,94 \pm 0,92$ & $24,80 \pm 0,97$ & $19,50 \pm 0,89$ & $123,00 \pm 4,06$ \\
\hline okur-yazar & $22,70 \pm 1,09$ & $19,80 \pm 0,91$ & $15,48 \pm 1,20$ & $19,06 \pm 1,01$ & $21,65 \pm 1,06^{\mathrm{ab}}$ & $18,55 \pm 0,97$ & $117,25 \pm 4,44$ \\
\hline ilkokul & $24,59 \pm 0,52$ & $21,28 \pm 0,43$ & $16,55 \pm 0,57$ & $20,27 \pm 0,48$ & $24,92 \pm 0,50$ & $19,44 \pm 0,46$ & $127,08 \pm 2,11$ \\
\hline ortaokul-lise & $23,91 \pm 0,51$ & $21,20 \pm 0,43$ & $17,11 \pm 0,56$ & $20,10 \pm 0,47$ & $25,06 \pm 0,50^{\mathrm{a}}$ & $18,88 \pm 0,46$ & $126,57 \pm 2,09$ \\
\hline üniversite & $24,41 \pm 0,64$ & $22,32 \pm 0,53^{\mathrm{a}}$ & $17,36 \pm 0,70$ & $20,22 \pm 059$ & $26,38 \pm 0,62^{b}$ & $20,50 \pm 0,57$ & $130,75 \pm 2,61$ \\
\hline \multicolumn{8}{|l|}{ Baba eğitim durumu } \\
\hline okur-yazar değil & $26,00 \pm 1,83$ & $23,50 \pm 1,53$ & $22,00 \pm 2,03$ & $21,75 \pm 1,70$ & $27,00 \pm 1,78$ & $22,00 \pm 1,64$ & $142,25 \pm 7,47$ \\
\hline okur-yazar & $24,75 \pm 1,71$ & $20,00 \pm 1,43$ & $15,12 \pm 1,89$ & $19,25 \pm 1,59$ & $23,87 \pm 1,66$ & $20,87 \pm 1,53$ & $123,87 \pm 6,99$ \\
\hline ilkokul & $24,36 \pm 0,61$ & $19,92 \pm 0,50$ & $15,98 \pm 0,67$ & $19,76 \pm 0,56$ & $25,09 \pm 0,45$ & $18,92 \pm 0,54$ & $124,05 \pm 2,48$ \\
\hline ortaokul-lise & $23,45 \pm 0,53$ & $21,19 \pm 0,44$ & $16,48 \pm 0,59$ & $19,89 \pm 0,49$ & $24,14 \pm 0,52$ & $19,21 \pm 0,47$ & $124,37 \pm 2,18$ \\
\hline üniversite & $24,30 \pm 0,47$ & $21,22 \pm 0,39$ & $17,01 \pm 0,52$ & $19,81 \pm 0,43$ & $25,09 \pm 0,45$ & $19,11 \pm 0,42$ & $126,80 \pm 1,92$ \\
\hline \multicolumn{8}{|l|}{ Kardeş sayısı } \\
\hline $1-2$ & $23,37 \pm 0,49$ & $21,12 \pm 0,46$ & $17,07 \pm 0,52^{\mathrm{a}}$ & $19,92 \pm 0,41$ & $25,01 \pm 0,51$ & $18,90 \pm 0,45$ & $125,40 \pm 2,11$ \\
\hline $3-4$ & $23,32 \pm 0,69$ & $20,32 \pm 0,65$ & $14,76 \pm 0,73^{\mathrm{a}}$ & $18,58 \pm 0,58$ & $24,30 \pm 0,72$ & $17,77 \pm 0,64$ & $119,99 \pm 2,97$ \\
\hline 5 ve üzeri & $25,18 \pm 0,96$ & $20,31 \pm 0,90$ & $16,51 \pm 1,01$ & $18,95 \pm 0,81$ & $23,87 \pm 1,00$ & $19,85 \pm 0,89$ & $124,69 \pm 4,11$ \\
\hline Beslenme şekli (ağırlı & & & & & & & \\
\hline karbonhidrat & $22,57 \pm 0,82$ & $20,01 \pm 0,77$ & $14,87 \pm 0,86^{\mathrm{a}}$ & $15,82 \pm 0,5^{\mathrm{ab}}$ & $24,22 \pm 0,85$ & $17,32 \pm 0,76$ & $116,76 \pm 3,51^{\mathrm{a}}$ \\
\hline protein & $24,90 \pm 0,95$ & $22,13 \pm 0,88$ & $19,47 \pm 1,00^{\mathrm{ab}}$ & $17,74 \pm 0,69^{\mathrm{a}}$ & $25,22 \pm 0,99$ & $19,52 \pm 0,88$ & $132,15 \pm 4,05^{a}$ \\
\hline meyve sebze & $26,33 \pm 1,95$ & $21,33 \pm 1,83$ & $17,83 \pm 2,06$ & $20,90 \pm 0,79^{b}$ & $23,66 \pm 2,04$ & $20,66 \pm 1,81$ & $133,50 \pm 8,34$ \\
\hline karışık & $23,60 \pm 0,48$ & $20,57 \pm 0,45$ & $15,82 \pm 0,51^{\mathrm{b}}$ & $23,66 \pm 1,64$ & $24,62 \pm 0,50$ & $18,91 \pm 0,44$ & $123,24 \pm 2,06$ \\
\hline Doğum yeri & & & & & & & \\
\hline Akdeniz & $23,63 \pm 0,50$ & $21,10 \pm 0,47$ & $17,61 \pm 0,53$ & $19,55 \pm 0,48$ & $25,19 \pm 0,48$ & $18,97 \pm 0,46$ & $126,07 \pm 1,99$ \\
\hline Doğu Anadolu & $22,56 \pm 1,27$ & $18,72 \pm 1,19$ & $14,64 \pm 1,35$ & $18,98 \pm 1,21$ & $24,50 \pm 1,21$ & $17,88 \pm 1,18$ & $117,29 \pm 5,04^{\mathrm{a}}$ \\
\hline Ege & $26,20 \pm 1,50$ & $23,10 \pm 1,40$ & $20,90 \pm 1,60^{\mathrm{ab}}$ & $22,70 \pm 1,43$ & $27,10 \pm 1,43$ & $22,10 \pm 1,39$ & $142,10 \pm 5,96^{\mathrm{ab}}$ \\
\hline Güneydoğu & $23,52 \pm 0,66$ & $20,21 \pm 0,62$ & $15,27 \pm 0,70^{\mathrm{a}}$ & $19,09 \pm 0,63$ & $23,49 \pm 0,63$ & $17,93 \pm 0,61$ & $119,52 \pm 2,63^{b}$ \\
\hline İç Anadolu & $22,50 \pm 1,53$ & $20,75 \pm 1,43$ & $15,50 \pm 1,63$ & $23,12 \pm 1,46$ & $24,00 \pm 1,46$ & $19,62 \pm 1,42$ & $125,50 \pm 6,08$ \\
\hline Karadeniz & $24,00 \pm 2,50$ & $16,00 \pm 2,34$ & $13,00 \pm 2,66$ & $18,00 \pm 2,39$ & $22,50 \pm 2,39$ & $19,00 \pm 2,33$ & $112,50 \pm 9,93$ \\
\hline Marmara & $21,37 \pm 1,65$ & $19,75 \pm 1,55$ & $12,62 \pm 1,76^{\mathrm{b}}$ & $18,37 \pm 1,58$ & $22,25 \pm 1,58$ & $19,37 \pm 1,54$ & $118,75 \pm 6,57$ \\
\hline Aylık gelir (aile) & & & & & & & \\
\hline$<700 \mathrm{TL}$ & $24,18 \pm 1,27$ & $22,43 \pm 1,15$ & $16,25 \pm 1,42$ & $20,56 \pm 1,12$ & $23,25 \pm 1,28$ & $19,56 \pm 1,24$ & $126,25 \pm 5,43$ \\
\hline 701-1450 TL & $23,07 \pm 0,83$ & $20,01 \pm 0,75$ & $14,63 \pm 0,93^{\mathrm{a}}$ & $18,52 \pm 0,74$ & $24,70 \pm 0,84$ & $19,05 \pm 0,82$ & $119,99 \pm 3,58$ \\
\hline $1451-2900 \mathrm{TL}$ & $24,54 \pm 0,59$ & $21,00 \pm 0,54$ & $17,24 \pm 0,66$ & $19,68 \pm 0,52$ & $25,02 \pm 0,60$ & $18,80 \pm 0,58$ & $126,31 \pm 2,55$ \\
\hline$>2900 \mathrm{TL}$ & $24,62 \pm 0,57$ & $20,72 \pm 0,51$ & $18,23 \pm 0,63^{\mathrm{a}}$ & $19,92 \pm 0,50$ & $24,91 \pm 0,57$ & $20,30 \pm 0,55$ & $128,97 \pm 2,44$ \\
\hline Aylık gelir (şahıs) & & & & & & & \\
\hline$<450 \mathrm{TL}$ & $24,63 \pm 0,57$ & $21,11 \pm 0,52$ & $16,91 \pm 0,64$ & $19,50 \pm 0,51$ & $24,37 \pm 0,58$ & $19,28 \pm 0,56$ & $126,05 \pm 2,46$ \\
\hline $451-900 \mathrm{TL}$ & $24,09 \pm 0,56$ & $20,57 \pm 0,50$ & $16,39 \pm 0,62$ & $19,47 \pm 0,49$ & $24,74 \pm 0,56$ & $19,29 \pm 0,55$ & $124,56 \pm 2,39$ \\
\hline$>900$ & $23,85 \pm 0,78$ & $20,99 \pm 0,70$ & $18,40 \pm 0,87$ & $20,27 \pm 0,69$ & $25,41 \pm 0,78$ & $20,23 \pm 0,76$ & $129,17 \pm 3,34$ \\
\hline Meslek memnuniyet & & & & & & & \\
\hline memnun olmayan & $22,83 \pm 1,87$ & $17,83 \pm 1,74$ & $14,83 \pm 1,98$ & $19,16 \pm 1,78$ & $22,83 \pm 1,78$ & $16,50 \pm 1,73$ & $114,00 \pm 7,40$ \\
\hline kısmen memnun & $20,68 \pm 0,77^{\mathrm{ab}}$ & $19,05 \pm 0,72^{\mathrm{a}}$ & $14,26 \pm 0,82^{\mathrm{a}}$ & $19,40 \pm 0,74$ & $23,25 \pm 0,74$ & $17,57 \pm 0,72$ & $115,56 \pm 3,08^{\mathrm{ab}}$ \\
\hline memnun & $24,16 \pm 0,52^{\mathrm{a}}$ & $20,40 \pm 0,48^{b}$ & $17,62 \pm 0,55^{\mathrm{a}}$ & $20,00 \pm 0,49$ & $25,19 \pm 0,50$ & $19,59 \pm 0,48$ & $126,99 \pm 2,07^{\mathrm{a}}$ \\
\hline çok memnun & $25,81 \pm 0,69^{b}$ & $22,78 \pm 0,64^{\mathrm{ab}}$ & $17,37 \pm 0,73$ & $20,39 \pm 0,65$ & $25,66 \pm 0,65$ & $19,71 \pm 0,64$ & $131,75 \pm 2,73^{b}$ \\
\hline Değişkenler & Manevi gelişim & $\begin{array}{c}\text { Sağlık } \\
\text { sorumluluğu }\end{array}$ & Egzersiz & Beslenme & $\begin{array}{c}\text { Kişilerarası } \\
\text { destek }\end{array}$ & Stresle başetme & Toplam \\
\hline Sigara kullanımı & & & & & & & \\
\hline var & $22,41 \pm 0,78$ & $18,78 \pm 0,73$ & $15,02 \pm 0,82$ & $17,11 \pm 0,66$ & $23,78 \pm 0,82$ & $17,20 \pm 0,72$ & $114,32 \pm 3,34$ \\
\hline yok & $24,66 \pm 0,54$ & $21,75 \pm 0,50$ & $16,70 \pm 0,57$ & $20,52 \pm 0,45$ & $24,99 \pm 0,56$ & $19,85 \pm 0,50$ & $129,21 \pm 2,32$ \\
\hline $\mathrm{p}$ değeri & 0,195 & $0,011^{*}$ & 0,971 & $0,000^{*}$ & 1,000 & $0,033^{*}$ & $0,004^{*}$ \\
\hline Alkol kullanımı & & & & & & & \\
\hline var & $22,16 \pm 0,99$ & $20,69 \pm 0,93$ & $17,84 \pm 1,04$ & $19,92 \pm 0,83$ & $23,90 \pm 1,03$ & $19,28 \pm 0,92$ & $123,83 \pm 4,23$ \\
\hline yok & $24,46 \pm 0,64$ & $19,91 \pm 0,60$ & $15,44 \pm 0,68$ & $19,09 \pm 0,54$ & $23,57 \pm 0,67$ & $18,81 \pm 0,60$ & $121,31 \pm 2,76$ \\
\hline p değeri & 0,546 & 1,000 & 0,565 & 1,000 & 1,000 & 1,000 & 1,000 \\
\hline Sistemik hastalık du & & & & & & & \\
\hline sağlıklı & $23,87 \pm 0,46$ & $20,24 \pm 0,43$ & $16,92 \pm 0,49$ & $19,90 \pm 0,44$ & $24,35 \pm 0,41$ & $19,23 \pm 0,42$ & $124,53 \pm 1,82$ \\
\hline hastalıklı & $22,98 \pm 0,56$ & $21,02 \pm 0,52$ & $15,60 \pm 0,60$ & $19,51 \pm 0,54$ & $24,61 \pm 0,54$ & $18,38 \pm 0,52$ & $122,86 \pm 2,24$ \\
\hline$p$ değeri & 0,224 & 0,256 & 0,091 & 0,580 & 0,710 & 0,207 & 0,563 \\
\hline Aile içi iletişim düzey & & & & & & & \\
\hline kötü & $25,12 \pm 1,65$ & $19,37 \pm 1,55$ & $16,37 \pm 1,76$ & $20,62 \pm 1,58$ & $23,37 \pm 1,58$ & $17,87 \pm 1,54$ & $122,75 \pm 6,57$ \\
\hline orta & $23,04 \pm 0,78$ & $20,71 \pm 0,73$ & $18,19 \pm 0,83$ & $19,98 \pm 0,74$ & $24,53 \pm 0,75$ & $18,79 \pm 0,73$ & $125,27 \pm 3,11$ \\
\hline iyi & $23,51 \pm 0,62$ & $20,91 \pm 0,51$ & $15,59 \pm 0,58$ & $19,23 \pm 0,52$ & $23,94 \pm 0,52$ & $18,72 \pm 0,50$ & $121,93 \pm 2,16$ \\
\hline çok iyi & $24,04 \pm 0,62$ & $20,63 \pm 0,58$ & $15,74 \pm 0,66$ & $20,26 \pm 0,59$ & $25,43 \pm 0,59$ & $19,71 \pm 0,58$ & $126,85 \pm 2,48$ \\
\hline Diş fırçalama sıklığı & & & & & & & \\
\hline günde 1 & $23,11 \pm 0,81$ & $18,64 \pm 0,73^{\mathrm{ab}}$ & $15,78 \pm 0,91$ & $17,71 \pm 0,72^{\mathrm{ab}}$ & $23,88 \pm 0,82$ & $18,92 \pm 0,79$ & $118,06 \pm 3,48^{\mathrm{a}}$ \\
\hline günde 2 & $24,97 \pm 0,46$ & $21,61 \pm 0,42^{\mathrm{a}}$ & $17,19 \pm 0,52$ & $19,91 \pm 0,41^{\mathrm{a}}$ & $24,78 \pm 0,47$ & $19,58 \pm 0,45$ & $128,24 \pm 1,99$ \\
\hline günde 3 ve üstü & $24,52 \pm 0,85$ & $21,63 \pm 0,77^{b}$ & $17,90 \pm 0,95$ & $21,54 \pm 0,75^{b}$ & $25,52 \pm 0,86$ & $20,56 \pm 0,83$ & $131,72 \pm 3,65^{a}$ \\
\hline ihtiyaç halinde & $22,42 \pm 1,29$ & $20,07 \pm 1,17$ & $16,57 \pm 1,45$ & $18,07 \pm 1,14$ & $24,42 \pm 1,30$ & $17,64 \pm 1,27$ & $119,21 \pm 5,55$ \\
\hline Diş hekimine gitme s & & & & & & & \\
\hline şikayeti olduğunda & $23,32 \pm 0,50$ & $20,30 \pm 0,46$ & $16,90 \pm 0,57$ & $19,33 \pm 0,45$ & $25,01 \pm 0,51$ & $19,16 \pm 0,50$ & $124,04 \pm 2,18$ \\
\hline $3-6$ ayda 1 & $24,95 \pm 0,72$ & $21,71 \pm 065$ & $17,23 \pm 0,81$ & $20,72 \pm 0,64$ & $24,81 \pm 0,73$ & $19,82 \pm 0,71$ & $129,70 \pm 3,11$ \\
\hline senede 1 & $25,00 \pm 1,01$ & $21,52 \pm 0,92$ & $15,98 \pm 1,13$ & $20,53 \pm 0,90$ & $24,97 \pm 1,02$ & $20,28 \pm 0,99$ & $128,29 \pm 4,35$ \\
\hline gitmiyor & $23,83 \pm 1,31$ & $22,16 \pm 1,18$ & $18,83 \pm 1,47$ & $19,83 \pm 1,16$ & $23,33 \pm 1,32$ & $20,50 \pm 1,28$ & $128,50 \pm 5,61$ \\
\hline
\end{tabular}

(*çok yönlü varyans analizi; $\mathrm{p}<0,05$ istatistiksel olarak anlamlıı̆ı ifade eder, aynı üst karakter küçük harfler istatistiksel olarak anlamlılığı ifade eder) 
arasında kadın ve erkek açısından herhangi bir fark olmadığı saptandı ( $p>0,05)$. Anne-eğitim durumu için, sağlık sorumluluğunun üniversite mezunu anneye sahip öğrencilerde okuma yazma bilmeyenlerinkine göre daha yüksek olduğu, kişilerarası destek alt grubunda ise hem üniversite hem de ortaokul-lise mezunu annelerin çocuklarının yalnızca okur-yazar olup okul okumayanlara göre daha yüksek puan aldıkları belirlendi $(p<0,05)$. Baba-eğitim durumunun ise aynı ölçeğin alt başlıklarına herhangi bir etkisi yoktu ( $p>0,05)$. (Tablo 3)

Ağırlıklı beslenme şekli protein olan grubun fiziksel aktivite skorlarının karbonhidrat ve karışık beslenenlere göre daha yüksek olduğu ve bu oranın istatistiksel olarak anlamlı olduğu saptandı $(p<0,05)$. Protein ve meyve sebze ağırıklı beslenen grup, karbonhidrat ile beslenenlere göre beslenme alt grubunda daha yüksek skora sahip olduğu gözlemlendi $(p<0,05)$. Sağlıklı yaşam biçimi davranış ölçeği toplamında da benzer şekilde protein ile beslenenlerin karbonhidrat ile beslenenlere göre daha yüksek puan aldıkları gözlendi. (Tablo 3)

Doğduğu ve büyüdüğü coğrafi bölge açısından Ege Bölgesindeki öğrencilerin Güneydoğu Anadolu ve Marmara Bölgesindeki bireylere göre fiziksel aktivite yönünden daha üstün oldukları saptandı. Toplamda ise Ege Bölgesi kütüğüne kayıtlı öğrencilerin yalnızca Güneydoğu Bölgesinden gelen öğrencilere daha üstün oldukları tespit edildi $(p<0,05)$. Diğer bölge öğrencileri ile arasında istatistiksel bir fark bulunamadı ( $p>0,05)$.(Tablo 3)
Gelir düzeyine göre ailesinin aylık geliri 2900 TL üzeri olan öğrenciler, fiziksel aktivite alt başlığında daha yüksek puan aldı $(p<0,05)$. Kendi aylık gelirinin ise herhangi bir başlıkta etkisinin olmadığı saptandı.(Tablo 3)

Bölüm memnuniyet düzeyi değerlendirildiğinde, herhangi bir şekilde memnuniyetini dile getiren öğrenci grubunun manevi gelişim yönünden kısmen memnun olduğunu bildiren öğrenci grubundan daha yüksek puan aldı $(p<0,05)$. Sağlık sorumluluğunun ise çok memnun olanlarda diğer iki gruba nazaran daha yüksek olduğu sonucuna ulaşıldı. Fiziksel aktivite yönüyle iyi skor alanların meslek memnuniyeti diğer gruplara göre anlamlı olarak daha yüksekti. Sağlıklı yaşam biçimi davranış ölçeği toplamında manevi gelişimde olduğu gibi benzer sonuçlar elde edildi.(Tablo 3)

Kötü alışkanlıklardan ikisi olan sigara ve alkol kullanımının öğrenciler üzerindeki etkisi incelendiğinde ise sigara kullanmayan bireylerin sağlık sorumluluğu, beslenme, stresle baş-edebilme kabiliyeti yönüyle ve toplamda daha yüksek skor elde ettiği tespit edildi $(p<0,05)$. Alkol kullanımının ise herhangi bir etkisinin olmadığı gözlendi. Benzer şekilde sistemik sağlık durumu ile aile içi iletişim düzeyinin de sağıklı yaşam biçimi davranış ölçeğine herhangi bir etkisinin olmadığı tespit edildi.(Tablo 3)

Dişlerini günde 2 ve daha fazla firçalayan grubun hem sağlık sorumluluğu hem de beslenme alt başlıklarında günde bir kez fırçalayanlara göre daha yüksek olduğu tespit edilmişken, intiyaç halinde fırçalayan öğrencilere göre herhangi bir üstünlüğü bulunamadı. Totalde günde üç ve daha fazla dişlerini

Tablo 4. Sağlıklı yaşam biçimi davranış ölçeğinin alt boyutları ve etkili nicel faktörlerin korelasyon analizi

\begin{tabular}{|c|c|c|c|c|c|c|c|c|}
\hline Değişkenler & & $\begin{array}{l}\text { Manevi } \\
\text { gelişim }\end{array}$ & $\begin{array}{c}\text { Sağlık } \\
\text { sorumluluğu }\end{array}$ & Egzersiz & Beslenme & $\begin{array}{c}\text { Kişilerarası } \\
\text { destek }\end{array}$ & $\begin{array}{c}\text { Stresle } \\
\text { başetme }\end{array}$ & Toplam \\
\hline \multirow{2}{*}{ Manevi gelişim } & Pearson correlation & 1 & ,373 & ,353 & 257 & ,609 & ,596 & ,734 \\
\hline & Önem düzeyi & - & ,000* & ,000* & ,000* & , $000 *$ & ,000* &, $000 *$ \\
\hline \multirow{2}{*}{$\begin{array}{l}\text { Sağlık } \\
\text { sorumluluğu }\end{array}$} & Pearson correlation & ,373 & 1 & 424 & 437 & 419 & ,388, & 710 \\
\hline & Önem düzeyi &, $000 *$ & - & ,000* &, $000 *$ & ,000* &, $000 *$ &, $000 *$ \\
\hline \multirow{2}{*}{ Egzersiz } & Pearson correlation & 353 & 424 & 1 & ,396 & 327 & 447 & ,685 \\
\hline & Önem düzeyi & ,000* & ,000* & - & ,000* &, $000 *$ & ,000* &, $000 *$ \\
\hline \multirow{2}{*}{ Beslenme } & Pearson correlation & 257 & 437 & ,396 & 1 & ,223 & 424 & ,629 \\
\hline & Önem düzeyi &, $000^{*}$ & $000 *$ &, $000 *$ & - &, $001^{*}$ &, $000^{*}$ &, $000^{*}$ \\
\hline \multirow{2}{*}{$\begin{array}{l}\text { Kişilerarası } \\
\text { destek }\end{array}$} & Pearson correlation & 609 & 419 & 327 & 223 & 1 & ,559 & ,730 \\
\hline & Önem düzeyi &, $000 *$ &, $000 *$ &, $000 *$ & ,001* & - &, $000 *$ &, $000 *$ \\
\hline \multirow{2}{*}{ Stresle baş-etme } & Pearson correlation & ,596 & 388 & 4447 & 424 & ,559 & 1 & ,794 \\
\hline & Önem düzeyi &, $000 *$ & ,000* & ,000* & ,000* &, $000 *$ & - &, $000 *$ \\
\hline \multirow{2}{*}{ Yaş } & Pearson correlation &,- 027 & 112 &,- 115 & 12 &,- 223 &,- 091 &,- 079 \\
\hline & Önem düzeyi & 693 & 102 & 093 & 863 & $001^{*}$ & 186 & 247 \\
\hline \multirow{2}{*}{$\begin{array}{l}\text { Vücut kitle } \\
\text { indeksi }\end{array}$} & Pearson correlation & ,005 &,- 026 & ,093 &,- 030 &,- 088 &,- 070 &,- 021 \\
\hline & Önem düzeyi & 936 & 704 & 173 & 662 & 199 & 304 & 762 \\
\hline
\end{tabular}

(* Pearson Korelasyon Analizi; $\mathrm{p}<0,05$ istatistiksel olarak anlamlılığı ifade eder) 
fırçalayan öğrencilerin günde bir kez fırçalayanlara nazaran daha yüksek skor elde ettikleri gözlendi $(p<0,05)$. Diş hekimine gitme sıklığının ise sağlıklı yaşam biçimi davranışlarının alt başlıklarına herhangi bir etkisi saptanamadı.(Tablo 3)

Manevi gelişim, sağlık sorumluluğu, fiziksel aktivite, beslenme, kişilerarası destek ve stresle başetme alt başlıklarının sağlıklı yaşam biçimi davranış ölçütü ile korelasyonu Tablo 4'te verilmiştir. Buna göre her bir alt boyutun ölçeğin toplam skoru ile korelasyon gösterdiği saptandı. Ayrıca vücut kitle indeksi ve yaş parametrelerinin de korelasyonu incelendi ve yaş artıkça kişilerarası destek puanının düştüğü saptanmış olup negatif yönlü bir korelasyon bulgusu elde edildi $(p=0,001)$. Vücut kitle endeksi ile sağlıklı yaşam biçimi arasında ise herhangi bir korelasyon tespit edilemedi.

\section{TARTIŞMA}

Sağlıklı olma düzeyini koruyacak ve yükseltecek her türlü davranış sağlıklı yaşam biçimi davranışı olarak tanımlanmaktadır. Bu çalışmada elde edilen bulgulara göre, bireylerin lisans eğitim düzeyi bireylerin sağlıklı yaşam biçimi davranış ölçütleri üzerinde anlamlı bir etkisi olmazken, sosyo-demografik verilerinin bireylerin sağlıklı yaşam biçimi davranış ölçütleri üzerinde anlamlı etkisi olduğu görülmüştür. Dolayısıyla bu çalışmanın sıfır hipotezi kısmen reddedilmiştir. Bu davranışlar arasında manevi gelişim, kişiler arası destek, dengeli ve düzenli beslenme, stresle baş-etme kabiliyeti, fiziksel aktiviteler ve sağlık sorumluluğu sayılabilmektedir. Pender'e göre sağlığı geliştirme modelinde yer alan bu ilkeler bireyin davranışlarını etkileyen öğrenme süreci üzerine doğrudan etki yapmaktadır. ${ }^{8}$ Güncellenerek kullanılan ve güvenilirliği ve geçerliliği kanıtlanmış sağlıklı yaşam biçimi davranış ölçeği II (SBYD II) dünya çapında birçok sağlık çalışanı veya sağlık sektörü öğrencilerinde kullanılmıştır. Örneğin, Al Kandari ve arkadaşlarının yaptığı bir çalışmada hemşirelik öğrencilerinin toplam puan ortalaması 128,16 bulunmuştur. ${ }^{12}$ Başka çalışmalarda yine aynı bölüm öğrencilerinin puan ortalaması ise 125,76 idi. $^{13}$ Tıp fakültesi araştırma görevlileri arasında yapılan bir çalışmada ise toplam puanın 111,1 olduğu saptandı. ${ }^{14}$ Diş hekimliği öğrencilerinin gerçekleştirdiği anket çalışmamızda tüm sınıfların ortalama sağlıklı yaşam biçimi davranış ölçeği puanının 125,84 olduğu tespit edildi. Ayrı ayrı sınıf düzeyinde ölçek puanı açısından anlamlı bir fark olmazken, en düşük ölçek puanı 4. sınıf düzeyinde $(124,41)$, en yüksek ölçek puanı ise 2. sınıf düzeyinde $(128,52)$ olmuştur. Ölçeğin üst sınırı olan 208 puan üzerinden alınan ortalama puanların diş hekimliği öğrencileri için sağlıklı yaşam biçimi davranışı sergileyebildiğini göstermektedir.

Ölçeğin alt boyutları olan manevi gelişim, sağlık sorumluluğu, fiziksel aktivite, beslenme, kişiler arası destek ve stresle baş-etme kavramlarının sağlıklı yaşam biçimi davranış biçimi ile pozitif yönlü bir korelasyon göstermiştir. Ölçeğin tüm maddelerinin birbiriyle tutarlı olduğunu gösteren bu bulgu yanıtların doğru bir şekilde yorumlanabilmesine imkân tanımaktadır. ${ }^{15}$

Diş hekimliği öğrencilerinin 16,73 puan ile en düşük fiziksel aktivite alt başlığında skor elde ettiği gözlenirken en yüksek puanı 24,92 ile kişiler arası destek alt başlığında ve 24,19 ile manevi gelişim alt başlığında sağladıkları dikkat çekmektedir. Ölçeğin tüm alt başlıklarında medyan değerin üzerinde puan elde etmişlerdir. Çeşitli çalışmalarda yapılan ölçek değerlendirmesinde en düşük puanın egzersiz alt başlığında elde edildiği bildirilmiştir. Çalışmamızın özellikle de bu verileri ile örtüşen sonuçlar elde edilen çalışmalar literatürde yer almaktadır. ${ }^{2,16,17}$ Fiziksel aktivite ve egzersizin düzenli olarak yapılması durumunda fiziksel ve fizyolojik iyi olma hali için oldukça faydalı olduğu tartışılmaz bir gerçektir. ${ }^{18}$ Ancak diş hekimliği öğrencilerinde ve hatta ayrı ayrı tüm sınıflarda en düşük puan fiziksel aktivite alt başlığında elde edilmişti. Bu bulgular doğrultusunda yoğun eğitim programı ve uygulamaya yönelik meslek dalı olması nedeniyle fiziksel aktivite için zaman ayırmanın ve egzersiz yapmanın diş hekimliği öğrencileri arasında yaygın olmadığı sonucuna varılabilir.

Anketimize katılan öğrencilerin 114'ü kadın 101 'i erkekti. Erkek ve kadınlar arasında sağlıklı yaşam biçimi davranışı alt gruplarının tamamında istatistiksel açıdan herhangi bir fark olmadığı tespit edildi. Çalışmamızdan farklı olarak literatürde kadınların sağlık sorumluluğu ve beslenme alt gruplarında daha yüksek puan aldıkları saptanmıştır. ${ }^{19,20}$ Başka bir çalışmada ise erkek öğrencilerin genel puan ortalaması kadınlara göre daha yüksekti. ${ }^{1}$ Ancak tüm bu çalışmalar diş hekimliği dışındaki üniversite öğrencilerinde yapılmıştır. Başka bir çalışmada ise birinci sınıf diş hekimliği öğrencilerinde yapılan değerlendirmede toplam puanda erkek ve kadın öğrenciler arasında istatistiksel açıdan herhangi bir fark bulunamamıştır. Bununla birlikte kadınların sağlık sorumluluğu erkeklerin ise fiziksel aktivite alt gruplarında anlamlı düzeyde daha yüksek puan aldıkları belirtilmektedir. ${ }^{21}$

Eğitim seviyesi yüksek ailelerde yetişen bireylerin sağlığın temel belirleyicilerinin ne olduğunu ve 
sağlığı tehdit edecek risk faktörlerini öğrenme güdüleri ve tehlikelere karşı takınacakları tavır önemli ölçüde etkilenmektedir. ${ }^{1}$ Çalışma sonuçlarından da görüleceği üzere diş hekimliği öğrencilerinin yarısından çoğunun anne ve baba eğitim seviyesinin yüksek olduğu saptanmıştır. Ancak sağlığı geliştirme davranışı üzerinde babadan ziyade annenin eğitim seviyesinin etkili olduğu açıkça görülmektedir. Zira çocuğun davranışlarının şekillendiği dönemde annenin sağlık davranışları ileride bireyin davranışlarına da önemli ölçüde yansıyacaktır. Bu çalışmada, annesi üniversite mezunu olan 50 öğrencinin sağlık sorumluluğu alt boyutunda daha yüksek puan aldığı gözlendi. Kişilerarası destek alt boyutunda da hem ortaokul-lise hem de üniversite mezunu anneye sahip öğrencilerin herhangi bir okuldan mezun olmayanlarınkine göre daha yüksek puan aldıkları saptanmıştı. Ancak ölçütümüzdeki diğer dört alt boyutta herhangi bir farklılık yoktu.

Kalabalık ailelerde yaşamanın dayanışma, duygu paylaşımı, manevi gelişim ve kişilerarası desteği artırmasının yanı sıra kişi başına düşen gelirin düşmesi, eğitim harcırahının azalması, fiziksel yaşam alanının azalması gibi dezavantajları da vardır. Kardeş sayısı 3 ve üzeri olan bireylerin sadece fiziksel aktivite alt başlığında daha yüksek puan aldıkları gözlendi. Diğer alt başlıklarda ise herhangi bir farklılık bulunamadı. Bu çalışmada kardeş sayısı ve kişi başı gelir ile yaşadığı ortam arasında korelasyon analizi yapılmadığı için herhangi bir çıkarımda bulunmak yanlış olacaktır. Zaten ailesinin aylık gelirinin 2900 TL üzeri olan öğrencilerin fiziksel aktivite alt başlığında 701-1450 TL arası olanlara göre daha yüksek puan aldığı, ancak daha düşük gelirli bireyler ile arasında fark olmadığı bu du- rumun tesadüfi olduğu yorumlanabilir. Çalışmamızın sonuçları Musavian ve arkadaşlarının üniversite öğrencilerinde yapmış oldukları çalışma sonuçları ile örtüşmektedir. ${ }^{1}$

Dengeli beslenme vücudun ihtiyacı olan ürünlerin temini ve enerji ihtiyacının karşılanmasının yanında vücut kitlesinin korunması veya ayarlanmasında sağlığa katkı sağlamaktadır. Kalsiyum ve D vitamini kemik metabolizmasında, protein kas kitlesinin artmasında, yağ ve karbonhidrat vücudun temel enerji ihtiyacında rol alır. ${ }^{22,23}$ Ağırlıklı olarak beslenme tipi sergileyen öğrenciler arasında özellikle de protein ağırıklı beslenenlerin karışık ve karbonhidrat ağırlıkı beslenenlere göre fiziksel aktivite alt grubunda daha yüksek puan aldıkları gözlendi. Benzer şekilde protein ve meyve-sebze ağırlıklı beslenenler karbonhidrat ile beslenenlere göre beslenme alt boyutunda daha yüksek puan aldı. Sağlıklı yaşam biçimi davranışları ölçek puanında ise protein ile beslenenlerin karbon- hidrat ağırlıklı beslenenlere göre daha sağlıklı aktiviteler içerisinde oldukları saptandı. Proteinin kas ağırlığının artmasındaki katkısı göz önünde bulundurul- duğunda egzersiz alt boyutunda daha yüksek olması kabul edilebilir bir durumdur. Meyve-sebze tüketiminin ise sağlıklı bir diyet programının önemli bir parçası olduğu ve diyet ile iliş̧ili hastalıklara karşı bireyi koruduğu, sonuç olarak kitle indeksi sınırları içerisinde kalmaya katkı sağlayacak önemli bilimsel kanıtları vardır.22 En azından karbonhidrat ağırlıklı beslenmenin beslenme alt boyutunda daha düşük puana sahip olması diş hekimliği öğrencilerinde besinler ile ilişkili hastalıkların farkındalığını ortaya koymaktadır.

Çalışmanın yapılmış olduğu Hatay Mustafa Kemal Üniversitesi Diş Hekimliği Fakültesi'nin coğrafi konumu ve jeopolitik yapısı nedeniyle üniversiteyi tercih eden öğrencilerin yine yakın bölgelerden geldiği gözlenmektedir. Buna yönelik anket sorumuzda verilen yanıtların sayısal değerleri dengesiz dağılmış ve istatistiksel bir veri ortaya koymamıza engel oluşturmuştur. Sonuç olarak Ege bölgesinde doğup büyüyen öğrencilerin Güneydoğu ve Marmara bölgesine göre fiziksel aktivite alt başlığında daha yüksek puan aldığı, ayrıca genel toplamda hem Doğu Anadolu hem de Güneydoğu bölgesindeki öğrencilere nazaran daha yüksek puan aldıkları tespit edilmiş olmasına karşın kesin bir kanıda bulunmak zordur.

Ülkemizde üniversite öğrencilerinin bilgi sahibi olmadan, çoğunlukla gelecek endişesi taşımaları nedeniyle meslek seçtikleri bilinmektedir. Anketimize katılan 215 öğrenciden yalnızca dördü memnuniyetsizlik bildirmiştir. Kısmen memnun olanların sayısı 35 iken geri kalanların büyük çoğunluğu memnun olduğu ifade etmiştir. Manevi gelişim, beslenme alt başlıklarında ve genelde memnun ve çok memnun olduğunu dile getiren öğrencilerin kısmen memnuniyet bildirenlere göre daha yüksek puan aldıkları, fiziksel aktivite alt başığında ise memnun olduğunu dile getirenlerin kısmen memnun olduğunu belirtenlere göre daha yüksek puan aldıkları gözlenmiştir. Yoğun tempoda geçen eğitim sürecinin memnuniyet düzeyinin artması ile korele olduğu ve bu durumun sağlıklı yaşam biçimi davranışlara yansıdığını bilimsel kanıt doğrultusunda ${ }^{24}$ söyleyebiliriz.

Alkol ve sigara gibi kötü alışkanlıklar sağlığı büyük ölçüde tehdit etmektedir. Kalp-damar rahatsızIıkları, solunum yolu hastalıkları ve karaciğer hastalıkları gibi rahatsızlıklarda sigara ve alkolün önemli bir etkisi vardır. Sigara ve alkolün tüketim sıklığının sağlık 
üzerinde önemli olduğu birçok çalışmada gösterilmiştir. Sigara toplumda yaygın olarak tüketilen sağlığı tehdit edici bir unsurdur. ${ }^{25-27}$ Çalışmamızda düzenli olarak sigara tükettiğini bildiren 60 öğrenci bulunmaktadır. Hiçbir şekilde sigara kullanmamış öğrencilerin ölçeğin tüm alt başlıklarda daha yüksek puan aldıkları gözlenmesine karşın, manevi gelişim, egzersiz/fiziksel aktivite ve kişiler arası destek alt boyutunda istatistiksel bir fark gözlenmedi. Alkol ve sistemik hastalık durumunun ise ölçeğin üzerinde herhangi bir etkisi olmadığı görüldü. Sigaraya kolay erişim, içilebilir alanların daha fazla oluşu ve maliyeti düşünüldüğünde kümülatif zarar verici boyutları daha ön plandadır. Bu nedenle sigaranın sağlıkı yaşam biçimi davranışlarına olumsuz etkisi olduğu sonucuna varılabilir.

Diş çürükleri ve dişeti problemleri gibi ağız hastalıkları sadece ağız bölgesindeki dokuları etkilemekle kalmaz aynı zamanda genel sisteme de olumsuz tesir edecek boyutlara ulaşabilmektedir. Bu nedenle ağız sağlı̆ı davranışları genel sağlık için de önemlidir. ${ }^{28}$ Çalışmamız çürük ve dişeti hastalı̆ııı saptamaya yönelik bir çalışma değildir. Ancak ağız sağlı̆ını geliştiren iki önemli unsur olan diş fırçalama sıklığı ve diş hekimi ziyaretleri yönünden sorgulandığında intiyaç halinde dişlerini fırçalayan yalnızca 9 öğrenci saptandı. Günde 2 kez ve daha fazla firçalayan öğrencilerin sağılk sorumluluğu ve beslenme alt boyutunda daha yüksek puan aldıkları, toplamda ise günde 3 kez firçalayanların 1 kez firçalayanlara nazaran daha yüksek skor elde ettikleri gözlendi. Diş hekimine gitme sıklığının sağlığı geliştirici davranışlar üzerinde ise herhangi bir etkisi bulunmadı. Düzenli diş fırçalamak diş çürüklerini ve dişeti hastalıklarına zemin hazırlayan dental plağın dişler üzerinde birikimini engellemektedir. Bu bilinç ile dişlerini firçalayan bireylerin bir sorumluluk duygusu taşıdığı çalışmamızın sonuçlarından anlaşılmaktadır.

Çalışmamızın dar bir bölgede ve belli bir popülasyon üzerinde yapılmış olması limitasyon olarak sayılabilir. Türkiye'deki diş hekimliği fakültesi öğrencileri üzerinde anketin yaygınlaştırıması ve ankete katılan öğrenci sayılarının demografik yönleriyle tutarlı olması anket sonuçlarının daha kesin yargılarla yorumlanmasını sağlayacaktır.

Bu anket çalışmasının limitasyonları dahilinde;

A. Diş hekimliği öğrencilerinin sağlıklı yaşam biçimi davranış ölçütünde ve alt boyutlarında sınıflar arasında bir fark olmadığı,

B. Cinsiyet farklıı̆ın sağıklı yaşam biçimi davranışlarına etki etmediği,

C. Anne-eğitim düzeyinin yükselmesinin sağlık sorumluluğu ve kişilerarası destek boyutunu geliştirdiği, baba-eğitim durumunun ise herhangi bir etkisinin bulunmadığı,

D. Kardeş sayısının artmasına bağlı olarak fiziksel aktivite alt boyutunda gelişme olduğu, ancak bilimsel bir çıkarım yapılamayacağı,

E. Protein-ağırıklı beslenme türünde karbonhidrat-ağırııkı beslenmeye göre sağıklı yaşam biçimi davranışlarında daha yüksek skor elde edildiği,

F. Coğrafi bölgeye göre kesin bir kanıda bulunmanın mümkün olmadığı,

G. Gelir düzeyinin ek herhangi bir katkı sağlamadığı,

H. Mesleki memnuniyetin sağlıkı yaşam biçimi davranışlarını olumlu etkilediği,

İ.Sigaranın sağılık sorumluluğu, beslenme, stresle başetme alt boyutunda ve toplamda oldukça önemli bir olumsuz etkisinin olduğu, alkol için aynı şeyin söylenemeyeceği,

J. Sistemik hastalık varlığı ve aile içi iletişim düzeyinin ölçütte herhangi bir öneminin olmadığı,

K. Diş fırçalama sıklığının sağılı sorumluluğu skorunu pekiştirdiği, beslenme skorunu olumlu yönde geliştirdiği ve total puana katkı sağladığı,

L. Diş hekimine gitme sıklığııın ise ölçeğin toplamı dâhil tüm alt boyutlarına ek herhangi bir etkisinin olmadığı, sonucuna ulaşılmıştır.

NOT: Calışmada herhangi bir yazar, kurum ya da kurulus ile çıkar çatışması içerisinde bulunmamaktadır. Makale daha önce hiçbir yerde yayınlanmamıs ve yayınlanmak üzere işlem görmemektedir.

\section{KAYNAKLAR}

1. Musavian AS, Pasha A, Rahebi SM, Atrkar Roushan Z, Ghanbari A. Health promoting Behaviors Among Adolescents: A Cross-sectional Study. Nurs Midwifery Stud 2014;3:e14560.

2. Yalçınkaya M, Özer FG, Karamanoğlu AY. Sağlık çalışanlarında sağlıklı yaşam biçimi davranışlarının değerlendirilmesi. Turk Silahlı Kuvvetleri Koruyucu Hekim Bul 2007;6:409-20.

3. Ayaz S, Tezcan S, Akıncı F. Hemşirelik yüksekokulu öğrencilerinin sağlığı geliştirme davranışları. Cumhuriyet Üniv Hemşirelik Yüksek Okulu Derg 2005; 9:26-34.

4. Galloway RD. Health promotion: causes, beliefs and measurements. Clin Med Res 2003;1:249-58.

5. Hogg W, Dahrouge S, Russell G, Tuna M, Geneau $R$ et al. Health promotion activity in primary care: performance of models and associated factors. Open Med 2009;3:e165-73.

6. Ghaffari M, Rakhshanderou S, Ramezankhani A, 
Noroozi M, Armoon B. Oral Health Education and Promotion Programmes: Meta-Analysis of $17-Y e a r$ Intervention. Int J Dent Hyg 2018;16:59-67.

7. Hosseini A, Choobineh A, Razeghi M, Pakshir HR, Ghaem $\mathrm{H}$ et al. Ergonomic Assessment of Exposure to Musculoskeletal Disorders Risk Factors among Dentists of Shiraz, Iran. J Dent (Shiraz) 2019;20:53-60.

8. Pender $\mathrm{NJ}$, Murdaugh $\mathrm{CL}$, Parsons $\mathrm{MA}$. Health promotion in nursing practice. (ed. 5). Upper Saddle River, NJ: Prentice Hall; 2006.

9. Walker SN, Sechrist KR, Pender NJ. The HealthPromoting Lifestyle Profile: development and psychometric characteristics. Nurs Res 1987;36:76-81.

10. Acikgoz Cepni S, Kitis Y. Relationship between healthy lifestyle behaviors and health locus of control and health-specific self-efficacy in university students. Jpn J Nurs Sci 2017;14:231-9.

11. Pinar R, Celik R, Bahcecik N. Reliability and construct validity of the Health-Promoting Lifestyle Profile II in an adult Turkish population. Nurs Res 2009;58:184-93.

12. Al-Kandari F, Vidal VL. Correlation of the healthpromoting lifestyle, enrollment level, and academic performance of College of Nursing students in Kuwait. Nurs Health Sci 2007;9:112-9.

13. Hawks RS, Madanat HN, Merill RM, Goudy MB, Miyagwa T. A cross-cultural comparison of health promoting behaviours among college students. The Int Electron J Health Educ 2002;5:84-92.

14. Çakır M, Piyal B, Aycan S. Healthy lifestyle behaviors and quality of life in physicians: a faculty of medicine based cross-sectional study. Ankara Med J 2015;15:209-19.

15. Bahar Z, Beşer A, Gördes N, Ersin F, Kıssal A. Sağlıklı yaşam biçimi davranışları ölçeği II'nin geçerlilik ve güvenirlik çalışması. Cumhuriyet Üniversitesi Hemşirelik Yüksek Okulu Dergisi 2008;12:1-13.

16. Hui WH. The health-promoting lifestyles of undergraduate nurses in Hong Kong. J Prof Nurs 2002;18:101-11.

17. Geçgil E, Yıldız S. Adölesanlara yönelik beslenme ve stresle başetme eğitiminin sağlığı geliştirmeye etkisi. Cumhuriyet Üniversitesi Hemşirelik Yüksek Okulu Dergisi 2006;10:19-28.

18. Teixeira PJ, Carraca EV, Markland D, Silva MN, Ryan RM. Exercise, physical activity, and selfdetermination theory: a systematic review. Int J
Behav Nutr Phys Act 2012;9:78.

19. Wei CN, Harada K, Ueda K, Fukumoto K, Minamoto $K$ et al. Assessment of health-promoting lifestyle profile in Japanese university students. Environ Health Prev Med 2012;17:222-7.

20. Aghamolaei T, Tavafian SS. Health behaviors of a sample of adolescents in bandar abbas, iran. Int J High Risk Behav Addict 2013;2:34-8.

21. Peker K, Bermek G. Predictors of health-promoting behaviors among freshman dental students at Istanbul University. J Dent Educ 2011;75:413-20.

22. Jones M, Pitt H, Oxford L, Bray I, Kimberlee R et al. Association between Food for Life, a Whole Setting Healthy and Sustainable Food Programme, and Primary School Children's Consumption of Fruit and Vegetables: A Cross-Sectional Study in England. Int $\mathrm{J}$ Environ Res Public Health 2017; 14:639

23. Dhillon J, Craig BA, Leidy HJ, Amankwaah AF, Osei-Boadi Anguah $\mathrm{K}$ et al. The Effects of Increased Protein Intake on Fullness: A MetaAnalysis and Its Limitations. J Acad Nutr Diet 2016;116:968-83.

24. Vural F, Dura AA, Fil Ş, Çiftçi S, Torun SÇ et al. The factors effecting healthcare employees satisfaction retention and organization commitment. Balikesir Sağlik Bil Derg 2012;1:137-44.

25. Kagee A, Dixon DN. Worldview and health promoting behavior: a causal model. J Behav Med 2000;23:163-79.

26. Fleming $P$, Godwin $M$. Lifestyle interventions in primary care: systematic review of randomized controlled trials. Can Fam Physician 2008;54:170613.

27. Eroymak S, Özkan O, Yeşilaydın G, Yılmaz ME. Sağlık yönetimi bölümü öğrencilerinin sağlıklı yaşam biçimi davranışlarının değerlendirilmesi. HÜSBED 2018;11:2382-402.

28. Nakre PD, Harikiran AG. Effectiveness of oral health education programs: A systematic review. J Int Soc Prev Community Dent 2013;3:103-15.

\section{Yazışma Adresi}

Dr. Öğretim Üyesi Osman Fatih ARPAĞ

Hatay Mustafa Kemal Üniversitesi

Diş Hekimliği Fakültesi Periodontoloji Anabilim

Dal/Hatay

Tel No: 0 (326) 2456060

Faks No: 0 (326) 2455060

Email: ofarpag@hotmail.com 